DOI: 10.12797/Politeja.12.2015.39.10

Mateusz FISZER

Uniwersytet Jagielloński

mateusz.fiszer@wp.pl

\title{
ŚWIĘTA WOJNA W BOŚNI I HERCEGOWINIE - GENEZA, AKTORZY, ZAGROŻENIA
}

\section{ABSTRACT Holy war in Bosnia and Herzegovina - origins, actors and threats}

The paper discusses the problem of mujahidin's activity in Bosnia and Herzegovina during the Bosnian war of 1992 to 1995. The author describes the background and the causes of the presence of holy warriors in Bosnia and Herzegovina, as well as the forms of financial and military support offered to them by the governments of Muslim countries, especially Iran and Saudi Arabia. The article presents also the organization of mujahidin's units, their influence on the internal situation of Bosnia and Herzegovina and the attitude of the Bosnian government towards the foreign warriors. According to the author, the presence of the mujabidin in the Balkans during the war was directly linked to the operation of international terrorist groups, which were given an opportunity to train and recruit volunteers for future terrorist attacks worldwide. The author also shows the role of Bosnian Muslim conservative communities in the global jihad.

Keywords: Bosnia and Herzegovina, terrorism, the mujahidin, the Bosnian war

Słowa kluczowe: Bośnia i Hercegowina, terroryzm, mudżahedini, wojna w Bośni 
$\mathrm{D}$ nia 6 grudnia 2012 roku sąd w Sarajewie skazał na 18 lat więzienia Mevlida Jašarevicia, 24-letniego Serba wyznania muzułmańskiego, który dokonał ataku na ambasadę Stanów Zjednoczonych w stolicy Bośni i Hercegowiny. 28 października 2011 roku ten pochodzący z Sandżaku ${ }^{1}$ wyznawca radykalnego odłamu islamu - wahabizmu, przez blisko godzinę ostrzeliwał z broni automatycznej placówkę dyplomatyczną USA. W ataku nie ucierpiał nikt z personelu dyplomatycznego, a jedynie bośniacki strażnik ambasady. Atak Jašarevicia zakończył się jego postrzeleniem przez lokalną policję.

Bośniacki sąd skazał Jašarevicia za akt terrorystyczny i orzekł najwyższy w historii Bośni i Hercegowiny wyrok za tego typu czyn. Równocześnie sędzia Branko Perić zauważył, że tego typu zdarzenie świadczy o rosnącym zagrożeniu terroryzmem w kraju, wynikającym między innymi z coraz większej popularności wahabizmu - niezwykle konserwatywnego odłamu islamu - na terenie Bośni i Hercegowiny. Sędzia wskazał, że gdyby nie obecność spoteczności wahabitów skupionej w miejscowości Gornja Maoča , nierespektujacej obowiazującego prawa państwowego i stawiajacej się ponad tymi regulacjami, nie dosztoby do aktu terroru, jakiego dopuścit sie Jašarević3.

Wyrok z grudnia 2012 roku został w listopadzie 2013 roku zmniejszony do 15 lat pozbawienia wolności (na skutek przeprowadzenia ponownego procesu), niemniej powyższe wydarzenia wskazują, że Bośnia i Hercegowina nie tylko narażona jest na ataki terrorystyczne, ale także stanowi teren działania grup o takim charakterze, a ich działalność może zarówno destabilizować sytuację wewnętrzną kraju, jak i - czy raczej przede wszystkim - stanowić poważne zagrożenie dla bezpieczeństwa europejskiego.

Niniejszy artykuł opisuje problem obecności i działalności grup mudżahedinów prowadzących na terytorium Bośni i Hercegowiny w trakcie i po zakończeniu krwawego konfliktu wewnętrznego z lat 1992-1995 świętą wojnę w imię Allaha. Przedstawia genezę zjawiska dżihadu na terytorium tej bałkańskiej republiki, sposób działania mudżahedinów oraz potencjalne zagrożenia wiążące się z ich działalnością na obrzeżach Unii Europejskiej.

\section{MUZUŁMAŃSCY WOJOWNICY W BOŚNI}

Nie budzi wątpliwości, że w czasie wojny, która toczyła się w latach 1992-1995, Bośnia i Hercegowina była areną walk na tle etnicznym oraz religijnym. Konflikt z początku lat 90. XX wieku zaliczany jest do jednych z najkrwawszych po II wojnie światowej. Oprócz regularnych armii każdej ze stron konfliktu, a później także międzynarodo-

\footnotetext{
Region na pograniczu Serbii i Czarnogóry zamieszkały przez dużą mniejszość muzułmańską.

2 Miejscowość znajdująca się na terytorium Bośni i Hercegowiny, w pobliżu autonomicznego dystryktu Brčko, będąca centrum wahabizmu na Bałkanach i pozostająca praktycznie poza kontrolą władz państwowych.

3 Bosnia US Embassy Gunman Mevlid Jasarevic Jailed for 18 Years, BBC News, [online] http://www. bbc.co.uk/news/world-europe-20629893, 15 V 2014. Wszystkie tłumaczenia tekstów anglojęzycznych w artykule pochodzą od autora.
} 
wych sił pokojowych, w Bośni na szeroką skalę pojawili się muzułmańscy ochotnicy (mudżahedin - arab. دماجد, dosł. „Święty wojownik”), którzy wspierani i opłacani przez różne organizacje z krajów muzułmańskich, głównie z Arabii Saudyjskiej, w tym także te mające związek z organizacjami terrorystycznymi, deklarowali oficjalnie wsparcie ludności muzułmańskiej w toczącym się konflikcie zbrojnym z Serbami i Chorwatami. Dla światowej społeczności muzułmańskiej wojna domowa w Bośni byta walka o zachowanie fizycznego istnienia Bośniaków $w^{4}$ ich narodowego i kulturalnego dziedzictwa, a także częścia globalnej walki o oczyszczenie i zjednoczenie narodu islamskiego ${ }^{5}$. Z czasem Bośnia stała się też miejscem, w którym ochotnicy mogli toczyć świętą wojnę przeciwko niewiernym w imię Allaha (dżihad - arab. داه ğ gihād - „zmaganie, walka”).

Warto zwrócić uwagę, że wybuch wojny na Bałkanach, z punktu widzenia mudżahedinów, nastąpił w odpowiednim momencie, niedługo po zakończeniu ich długoletnich walk przeciw Związkowi Radzieckiemu w Afganistanie. Sytuacja w Bośni była wręcz doskonałą okazją do podtrzymywania świętej wojny i dalszego treningu oddziałów mudżahedinów w warunkach realnego konfliktu.

Równocześnie także sytuacja międzynarodowa, w tym zwłaszcza początkowe niezdecydowanie administracji USA co do zaangażowania się po którejś ze stron konfliktu, umożliwiła mudżahedinom właściwie nieskrępowany napływ w rejon walk. Ich obecność w regionie była na rękę wielu zainteresowanym stronom. Osamotniona na arenie międzynarodowej muzułmańska Bośnia, dzięki zaangażowaniu dodatkowych sił walczących po jej stronie, otrzymywała wsparcie militarne, a także moralne oraz logistyczne. Przywódcy USA żywili nadzieję, że mudżahedini, którzy w Afganistanie wystąpili przeciw ZSRR, pomogą im uzyskać wpływy wśród ludności muzułmańskiej i będą dbali o amerykańskie interesy.

Zdecydowana większość mudżahedinów trafiała do Bośni jako przedstawiciele jednej z licznie działających w tym czasie na Bałkanach muzułmańskich organizacji humanitarnych, pod pretekstem niesienia pomocy ludności cywilnej dotkniętej toczącym się konfliktem zbrojnym. W latach 1992-1995 już 33 takie organizacje działały aktywnie na terytorium Chorwacji i Bośni. Ich liczba znacznie wzrosła po zakończeniu konfliktu zbrojnego i w 1996 roku w samej Bośni i Hercegowinie zarejestrowanych było ponad 200 zagranicznych organizacji humanitarnych (w tym większość z nich miała siedziby w krajach muzułmańskich). Nie bez znaczenia jest także okoliczność, że wiele ze wskazanych organizacji miało bardzo dobre relacje z władzami w Sarajewie.

Należałoby także zaznaczyć, że wielu wolontariuszy, którzy przybyli do Bośni, dziatato w poczuciu misji religijno-ideologicznej. Wierzyli, że ciężki los bośniackich muzutmanów jest rezultatem ich odejscia od korzeni islamskich i że musza dlatego być przywróceni czystej wierze i praktykom wczesnego islamu, tj. salafizmu. Chociaż bośniackim

Istnieje różnica pojęciowa między Bośniakami a Boszniakami. Pierwsze z pojęć dotyczy mieszkańców państwa Bośnia i Hercegowina, drugie - słowiańskiej ludności muzułmańskiej zamieszkującej przede wszystkim tereny Bośni i Hercegowiny.

A. Ceresnjes, R. Green, Ruch globalnego dżhadu w Bośni - bomba zegarowa w sercu Europy, przeł. M. Koraszewska, The MEMRI, VI 2012, [online] http://www2.memri.org/bin/polish/articles. cgi Page $=$ archives\&Area $=$ ia\&ID $=I A 85012,15$ V 2014. 
muzutmanom byto to obce, dla salafitów arabskich stanowito zasadniczy element ich globalnej walki ${ }^{6}$. W tym miejscu warto zaznaczyć, że tradycyjnie bośniaccy muzułmanie to w większości hanafici - wyznawcy najbardziej liberalnej i otwartej światopoglądowo szkoły islamu sunnickiego, która dąży do dialogu i akceptuje odmienności w łonie nauk islamu. Niemniej jednak pojawienie się mudżahedinów, świętych wojowników walczących w imię islamu, wychowanych w tradycji wahabistycznej, stało się dla niektórych, nielicznych, Bośniaków atrakcyjną alternatywą.

\section{ŹRÓDŁA FINANSOWANIA DZIAŁALNOŚCI MUDŻAHEDINÓW}

Prowadzenie przez mudżahedinów świętej wojny w imię Allaha na terenie Bośni i Hercegowiny ${ }^{7}$ nie byłoby możliwe bez zewnętrznych źródeł finansowania, w tym zwłaszcza funduszy i wsparcia oferowanych przez Arabię Saudyjską. Rijad zaangażował się w bałkański konflikt, upatrując w nim szansę na szersze propagowanie idei wahabizmu na świecie i zyskanie „przyczółku” pozwalającego na rozpoczęcie budowy siatki wpływów na Starym Kontynencie.

Wahabizm, będący radykalnym nurtem islamu dominującym w kraju rządzonym przez dynastię Saudów, głosi postulaty powrotu do źródeł islamu, prostoty i surowości obyczajów. Równocześnie uznaje wszelkie inne nurty islamu za heretyckie i dąży do nawracania „zbłądzonych muzułmanów” na jedyną prawdziwą ścieżkę wiary. Fundamentalizm światopoglądowy wyznawców tego nurtu odwołuje się także do haseł antyamerykańskich i antysyjonistycznych. W najbardziej skrajnych odmianach wahabici deklarują także wrogość w stosunku do postępu i modernizacji.

Powyższe ideały miały być, w myśl zamierzeń Rijadu, propagowane przez islamskich bojowników wśród bośniackich muzułmanów. W celu umożliwiania eksportu idei wahabizmu w Bośni rozpoczęły na szeroką skalę działalność saudyjskie organizacje pozarządowe, które, wbrew swojej nazwie, wspierane i finansowane były funduszami państwowymi przez władze saudyjskie. Wśród najistotniejszych organizacji tego typu należy wymienić w szczególności International Islamic Relief Organization (IIRO) oraz jej matczyną organizację - Światową Ligę Muzułmańską (Muslim World League - MWL). Obie organizacje powołane zostały do życia przez rząd Arabii Saudyjskiej celem rozprzestrzeniania ideałów wahabistycznych i były przez niego finansowane. Ich zadaniem było zachęcanie islamistów z całego świata do podjęcia walk w Bośni i organizacja przerzutu rekrutów na Bałkany. Ochotnicy trafiali na tereny Bośni przez Zagrzeb za cichym przyzwoleniem zarówno władz chorwackich, jak i społeczności międzynarodowej. Warto zaznaczyć, że mudżahedini działali najczęściej pod przykrywką wolontariuszy tych organizacji (posiadali stosowne dokumenty potwierdzające ten status), często podszywali się także pod pracowników ONZ czy międzynarodowych reporterów relacjonujących wydarzenia $\mathrm{z}$ frontu walk.

\section{Tamże.}

W dalszej części termin „Bośnia” należy także rozumieć jako odwołujący się do Bośni i Hercegowiny. 
Zarówno IIRO, jak i MWL cieszyły się sympatią i przychylnością władz w Sarajewie, które z nieukrywanym zadowoleniem przyjmowały nie tylko samych mudżahedinów, ale także idące za nimi pieniądze, broń i amunicję niezbędne do skutecznego prowadzenia działań wojennych. Nie można bowiem zapominać, że będąca u władzy Partia Akcji Demokratycznej (Stranka Demokratske Akcije - SDA) pod kierownictwem prezydenta Aliji Izetbegovicia, nie otrzymawszy na arenie międzynarodowej poparcia dla interwencji wojskowej w Bośni mającej zapobiec rozlewowi krwi, sama zwróciła się o pomoc do krajów muzułmańskich, w tym do Arabii Saudyjskiej.

Za najważniejszą z organizacji islamskich wspierających działania mudżahedinów w Bośni należałoby jednak uznać założoną w 1987 roku w Wiedniu Third World Relief Agency (TWRA), której fundatorem był Sudańczyk Fatih al-Hasanayn. W latach 70. XX wieku studiował w Belgradzie medycynę ${ }^{8}$, a po ukończeniu studiów rozpoczął praktykę zawodową w Wiedniu. Z czasem postanowił poświęcić się działalności na rzecz propagowania radykalnego islamu we wschodniej Europie i na Bałkanach.

Po upadku bloku wschodniego na przełomie lat 80. i 90. XX wieku al-Hasanayn rozwinął na szeroką skalę swoją działalność i rozpoczął zbiórkę pieniędzy na rzecz propagowania islamu w Europie. Rolą TWRA było zbieranie w krajach islamskich funduszy, które następnie kierowane były na Bałkany w celu wspierania walczących muzułmanów. Szeroki strumień środków z Arabii Saudyjskiej, Iranu czy Sudanu wpływający na konta TWRA wykorzystywano w głównej mierze na zakup broni i amunicji. Bałkańskie centrum operacyjne TWRA znajdowało się w Zagrzebiu, gdzie dzięki przychylności prezydenta Chorwacji Franjo Tudjmana dwóch członków SDA, imam Mustafa Cerić oraz Salim Šabić, prowadziło biuro TWRA.

Trudno do dzisiaj jednoznacznie ustalić, ile pieniędzy przeszło przez konta TWRA w trakcie konfliktu wojennego na Bałkanach. Niektóre szacunki wskazują, że mogło to być ponad 2,5 mld USD9 , z czego istotna część została zdefraudowana przez skorumpowanych polityków SDA. TWRA kontrolowała całą pomoc napływającą do Bośni z krajów islamskich. Warto wspomnieć, że we władzach organizacji zasiadali, oprócz al-Hasanayna, najbliżsi współpracownicy prezydenta Izetbegovicia: Hasan Čengić, Irfan Ljevaković, Husein Zivalj i Derviš Djurdjević, którzy decydowali o przeznaczeniu pieniędzy na określone cele (przy większych kwotach decyzje uzgadniano bezpośrednio $\mathrm{z}$ samym Izetbegoviciem).

TWRA współpracowała blisko z Osamą bin Ladenem oraz z szejkiem Omarem Abdel-Rahmanem ${ }^{10}$, a także ze wspomnianą powyżej IIRO. Ludzie al-Hasanayna byli odpowiedzialni za gromadzenie funduszy potrzebnych na broń i amunicje, podczas gdy

W tym czasie po raz pierwszy spotkał się z Aliją Izetbegoviciem.

9 J.R. Schindler, Unholy Terror. Bosnia, Al-Qa'ida and the Rise of Global Jihad, St. Paul 2007, s. 149; znacznie mniejszą kwotę, ponad $350 \mathrm{mln}$ USD, wskazuje natomiast I. Lučić, Bosnia and Herzegovina and Terrorism, „National Security and the Future” 2001, Vol. 3-4, nr 2, s. 127.

10 Przywódca muzułmański pochodzenia egipskiego, walczący jak mudżahedin w trakcie wojny w Afganistanie, skazany na karę śmierci za organizację zamachu terrorystycznego na World Trade Center w Nowym Jorku w 1993 r. 
Saudyjczycy wydawali pieniadze na wszystko inne zwiąane z prowadzeniem dżihadu $w$ Bośni ${ }^{11}$. TWRA prowadziło interesy niemalże ze wszystkimi islamskimi organizacjami pozarządowymi działającymi na Bałkanach. Jego znaczenie było nie do przecenienia przez kierownictwo SDA, gdyż bez niego prowadzenie jakichkolwiek działań przez Aliję Izetbegovicia byłoby najprawdopodobniej niemożliwe.

Pomoc na rzecz walczących w Bośni muzułmanów nie miała tylko charakteru pieniężnego. Wśród darczyńców przekazujących wsparcie dla walczących Bośniaków był szereg krajów muzułmańskich, w tym między innymi Pakistan, który dostarczał wysokiej klasy pociski antyczołgowe. W późniejszym okresie pomoc oferowały także działające w ramach misji ONZ Turcja, Malezja i Bangladesz, których oddziały były zaopatrywane w przewyższającą ich realne potrzeby broń i amunicję. Nadwyżki sprzedawano na rzecz bośniackich muzułmanów.

Inną islamską organizacją, która wspierała dżihad w Bośni, była Benevolence International Foundation (BIF). Celem statutowym tej powstałej na terenie USA organizacji non-profit było niesienie pomocy humanitarnej na świecie. BIF kontynuowała działania innej organizacji, Islamic Benevolence Committee, zbierającej środki na rzecz wojowników w Afganistanie w latach 80. XX wieku. Organizacja ta współpracowała z Al-Ka’idą. Zgodnie z ustaleniami dokonanymi przez CIA na podstawie dokumentów znalezionych w trakcie przeszukania siedziby BIF w 2002 roku, kierujący jej działalnością operacyjną Syryjczyk o albańskich korzeniach Enaam Arnaout posiadał pełnomocnictwo Osamy bin Ladena do podpisywania w jego imieniu dokumentów. Do dzisiaj nie udało się jednak ustalić dokładnej kwoty udzielonej przez BIF pomocy, jaka trafiła do Bośni, gdyż większość jej operacji finansowych nie była oficjalnie rejestrowana (donacji udzielano w oparciu o system honorowych przekazów pieniężnych - hawala które zasadniczo nie są nigdzie rejestrowane).

Oprócz saudyjskiego wsparcia bojownicy działający w Bośni otrzymali także pomoc ze strony Iranu, który podobnie jak Arabia Saudyjska dążył do zaznaczenia swojej obecności w Europie i budowy przyczółku do ewentualnych dalszych działań wywiadowczych na Starym Kontynencie. Nie bez znaczenia dla zaangażowania Teheranu w działania na terenie Bośni była chęć przeciwstawienia się rosnącym wpływom Arabii Saudyjskiej na Bałkanach.

Władzom w Sarajewie na rękę było pozyskanie kolejnego sojusznika, zwłaszcza że szyizm ajatollahów był im ideologicznie bliższy niż saudyjski wahabizm, dlatego też chętnie zdecydowały się skorzystać z pomocy Teheranu.

Irańska pomoc dotyczyła przede wszystkim kwestii militarnych i nie miała aż tak ideologicznego charakteru jak wsparcie oferowane przez saudyjskich władców. Iran stał się wprawdzie adwokatem sprawy bałkańskich muzułmanów na arenie międzynarodowej, jasno i dobitnie piętnując okrucieństwa popełniane przez Serbów, niemniej jednak w centrum zainteresowania obu stron pozostawała pomoc militarna w postaci dostaw broni i amunicji oraz prowadzenie szkoleń dla żołnierzy Armii Bośni i Hercegowiny.

11 J.R. Schindler, Unholy Terror.., s. 153. 
Mimo międzynarodowego embarga na dostawę broni Iran rozpoczął jej przerzut na terytorium Bośni już w pierwszej połowie 1992 roku. Dostawy realizowane były poprzez port lotniczy w Zagrzebiu, za cichym przyzwoleniem chorwackich władz, które zresztą miały czerpać finansowe korzyści z przerzutu broni do Bośni. Chociaż proceder był niezbyt starannie zakamuflowany, a o całej sprawie wiedziały zarówno władze USA, jak i rządy państw zachodniej Europy, to nie doszło do podjęcia żadnych kroków, które miałyby go ukrócić.

Powyższe fakty doskonale podsumowuje następująca relacja: Prezydent Clinton nieoficjalnie dat przyzwolenie na tajne irańskie dostawy broni do Bośni w 1994 roku pomimo natożonego przez ONZ embarga, o którego utrzymanie wnosity same Stany Zjednoczone, oraz prowadzonej przez Waszyngton polityki izolacji Teheranu na arenie międzynarodowej jako światowego stronnika terroryzmu [...]. Dwóch wysokich ranga amerykańskich dyplomatów, dziatających zgodnie z instrukcjami Biatego Domu oraz Departamentu Stanu, miato powiedzieć prezydentowi Chorwacji Franjo Tudjmanowi na poczatku 1994 roku, że USA nie będa się sprzeciwiać utworzeniu jakiegokolwiek kanatu przerzutu broni przez Chorwacje do Bośni i Hercegowiny. [...] Operacja przerzutu broni trwata [...] nawet po rozlokowaniu prawie 20000 amerykańskich żotnierzy w ramach operacji sit pokojowych w Bośni ${ }^{12}$.

Rząd w Teheranie wysyłał do Bośni nie tylko pomoc militarną czy wojskowych specjalistów, ale także licznych agentów VEVAK (potoczna nazwa Ministerstwa Wywiadu i Bezpieczeństwa Narodowego, pers. Vezarat-e Ettela’at va Amniyat-e Keshvar) oraz Pasdaran (członkowie Islamskiego Korpusu Strażników Rewolucji, pers. Sepāh-e Pāsdārān-e Enqelāb-e Eslāmi), którzy bardzo sprawnie rozbudowywali siatkę wywiadowczą. Szacuje się, że liczba samych pasdaranów działających na terenie Bośni w 1995 roku wynosiła blisko 2 tys. ${ }^{13}$ Oprócz działań wywiadowczych na rzecz Teheranu, polegających także na infiltracji kierownictwa SDA, agenci prowadzili szkolenia dla bośniackiego wywiadu, obejmujące naukę zarówno z zakresu techniki działań wojennych, jak i z zakresu stosowania narzędzi potrzebnych do przeprowadzania działań terrorystycznych.

Pod koniec wojny rozprzestrzenienie się siatki agentów wywiadu Iranu, wrogo nastawionego zwłaszcza do USA, działającego pod przykryciem dyplomatycznym, wojskowym, dziennikarskim czy charytatywnym, zaczęło być coraz bardziej kłopotliwym tematem dla rządu w Sarajewie. Po Porozumieniu z Dayton i pojawieniu się sił stabilizacyjnych na terytorium Bośni zakrojone na szeroką skalę działania wywiadowcze VEVAK oraz Pasdaran, a także prowadzona przez te służby działalność szkoleniowa również na rzecz mudżahedinów zaczęły bezpośrednio zagrażać bezpieczeństwu amerykańskich wojsk. Mimo wcześniej stosowanej taktyki odwracania wzroku od problemu irańskiej infiltracji Waszyngton postanowił podjąć zdecydowane kroki.

12 House Republican Policy Committee, Policy Perspective. The Clinton Administration's „Wink and Nod" to Allow Iran into Bosnia. Iran-Bosnia Credibility Gap, 26 IV 1996, [online] http://www.fas.org/ irp/news/1996/hrpc_irancred.htm, 26 V 2014. 
W lutym 1996 roku siły IFOR ${ }^{14}$ przeprowadziły operację specjalną mającą na celu likwidację jednego z centrum szkoleniowych VEVAK w położonej w górach osadzie Pogorelica, która oficjalnie stanowiła farmę produkującą żywność na potrzeby Armii Bośni i Hercegowiny. W rzeczywistości było to dobrze zorganizowane centrum szkoleniowe, w którym bośniackie tajne służby pobierały nauki od irańskich trenerów w zakresie sztuk walki, sabotażu, przeprowadzania ataków bombowych. W czasie akcji zatrzymano kilku Bośniaków i czterech oficerów wywiadu Iranu. Na terenie ośrodka znaleziono potężny arsenał broni, materiałów wybuchowych i min.

Zatrzymani w trakcie akcji irańscy agenci oraz zabezpieczona broń jasno wskazywały, że siły IFOR zlikwidowały bazę szkolącą terrorystów. Równocześnie wydarzenia te postawily w trudnej sytuacji samego prezydenta Izetbegovicia, który nierzadko solennie zarzekał się, że na terenie Bośni nie ma żadnych bojowników islamskich ani przedstawicieli obcych wywiadów. W obliczu omawianej akcji trudno było mu w dalszym ciągu podtrzymywać to stanowisko, dlatego też, nie chcąc stracić poparcia Zachodu, zdecydował się przyznać do obecności agentów irańskiego wywiadu, choć jednocześnie zapewnił, że problem ich działalności na terenie Bośni i Hercegowiny został rozwiązany, gdyż Irańczycy opuścili już teren kraju. Po dwóch latach od akcji w Pogorelicy amerykański wywiad opublikował raport, w którym wskazano na ciągle liczną obecność agentury irańskiej w Bośni i jej kontakty z ludźmi z najbliższego otoczenia ścisłego kierownictwa SDA.

\section{ORGANIZACJA ODDZIAŁÓW ZAGRANICZNYCH MUDŻAHEDINÓW ${ }^{15}$}

Wspomniane wsparcie społeczności muzułmańskiej umożliwiło mudżahedinom przybycie na teren Bośni najprawdopodobniej już w połowie 1992 roku. Ochotnicy chcący wziąć udział w dżihadzie rekrutowali się w szczególności z krajów Afryki Północnej, Bliskiego Wschodu i Środkowego Wschodu. Znaczna część ochotników pochodziła z Arabii Saudyjskiej. Ich liczba do dzisiaj nie została potwierdzona. Źródła różnią się w szacunkach, wskazując, że mogła się ona wahać w przedziale od 1,2-1,4 tys. do nawet 3 tys. ${ }^{16}$

Większość bojowników dotarła na tereny Bośni przez Chorwację za cichą zgodą chorwackiego rządu. Islamskie Centrum Kulturalne w Zagrzebiu prowadzone przez

14 Implementation Force - międzynarodowe siły wojskowe działające na podstawie mandatu ONZ i pod przywództwem NATO, odpowiedzialne za kontrolę wprowadzania w życie zapisów Porozumienia z Dayton; po wyczerpaniu się udzielonego mandatu zastąpione w 1996 roku siłami SFOR (Stabilization Force).

15 Opracowano na podstawie wyroku MTK z 15 IX 2008 r., w sprawie Oskarżenie v. Rasim Delić, sygn. IT-04-83-T.

16 A. Ceresnjes, R. Green, Ruch globalnego dżihadu... Schindler podaje jeszcze wyższe szacunki zbliżone do liczby 5-6 tys., zob. J.R. Schindler, Unholy Terror..., s. 162. Podobne szacunki przedstawia też V. Attanassoff, Islamic Revival in the Balkans, Monterey, Calif. 2006, s. 30. 
Salema Šabicia i Šemsudina Tankovicia było prężnie działającym środowiskiem, mającym możliwość sprawnej organizacji przerzutu ochotników do walki w imię islamu do Bośni ${ }^{17}$. Także ówczesny przywódca duchowy wspólnoty muzułmańskiej Bośni i Hercegowiny Mustafa Cerić, który w kwietniu 1993 roku przybył na teren Bośni, był silnie związany z islamskim środowiskiem Zagrzebia, sprawując przez jakiś czas funkcję imama zagrzebskiego meczetu.

Pomimo oficjalnych deklaracji Aliji Izetbegovicia, składanych przez większą część trwania konfliktu zbrojnego w Bośni w latach 90. XX wieku, na temat tego, że w walkach nie biorą udziału żadne jednostki islamskich wojowników, obecność mudżahedinów walczących po stronie muzułmańskiej w trakcie konfliktu na Bałkanach była tajemnicą poliszynela. Co więcej, ich obecność i udział w walkach były podyktowane przede wszystkim celami politycznymi, a nie militarnymi. Wojownicy jawnie deklarujący swoje powołanie jako obrońcy islamu, przywiązani do konserwatywnych tradycji wahabitów, byli potrzebni kierownictwu SDA, w tym przede wszystkim Aliji Izetbegoviciowi dążącemu do utworzenia w Bośni republiki islamskiej w Europie.

Znaczna część ochotników pojawiła się w okolicach miejscowości Travnik i Zenica w środkowej Bośni. Początkowo grupy zagranicznych wojowników nie stanowily zorganizowanych jednostek, działały niezależnie od oddziałów Armii Bośni i Hercegowiny $(\mathrm{BiH})$ i starały się nie zwracać większej uwagi na swoją działalność.

Z czasem jednak ich obecność została zauważona przez 3 Korpus Armii BiH, który wskazał naczelnemu dowództwu w Sarajewie na problem zagranicznych bojowników operujących na terenie Bośni. Ich działalność jako niezorganizowanych jednostek walczących po stronie ludności muzułmańskiej poza oficjalnymi strukturami militarnymi budziła wątpliwości co do legalności i mogła być źródłem problemów wizerunkowych dla Armii BiH, zwłaszcza wziąwszy pod uwagę pogłoski o brutalności działań bojowników i dokonanych mordach na ludności serbskiej i chorwackiej. Problemem był także status żołnierzy Armii BiH, którzy zauważywszy lepsze wyposażenie oraz wyższe morale w oddziałach mudżahedinów, dołączali do nich, porzucając macierzyste jednostki i narażając się na zarzut dezercji.

Powyższe okoliczności zadecydowały o podjęciu w sierpniu 1993 roku przez dowództwo Armii BiH decyzji o włączeniu i podporządkowaniu mudżahedinów $7 \mathrm{Mu}-$ zułmańskiej Brygadzie Armii Bośni i Hercegowiny oraz utworzeniu specjalnej jednostki w batalionie nazywanej El Mudžahid albo Kateebat al- Mujahideen. Pewne wątpliwości budzi rzeczywiste podporządkowanie zagranicznych rekrutów dowództwu bośniackiemu. W jednym ze swoich orzeczeń w sprawie dotyczącej dowódców Armii Bośni i Hercegowiny, Envera Hadžihasanovicia (dowódca 3 Korpusu Armii $\mathrm{BiH}$ oraz członek sztabu Armii BiH) i Amira Kubura (dowódca 7 Muzułmańskiej Brygady 3 Korpusu Armii BiH), Międzynarodowy Trybunał Karny dla byłej Jugosławii (MTK) stwierdził, że brak przekonujących dowodów przemawiających za stwierdzeniem, iż zagraniczni mudżahedini oficjalnie dołączyli do struktur Armii $\mathrm{BiH}$ i byli bezpośrednio podporządkowani jej dowództwu. Niemniej jednak część badaczy

17 I. Lučić, Bosnia and Herzegovina..., s. 126. 
twierdzi, że jednostka El Mudžahid była w pełni zintegrowana organizacyjnie z Armią $\mathrm{BiH}$, o czym świadczyć może między innymi fakt, że jej dowódcy otrzymywali żołd tak jak zwykli żołnierze ${ }^{18}$.

Także zeznający przed MTK w sprawie przeciw bośniackiemu generałowi Rasimowi Deliciowi jako świadkowie oskarżenia arabscy ochotnicy wskazali, że jednostka El Mudžahid była formalnie podporządkowana dowództwu Armii BiH, chociaż w wielu aspektach znacząco różniła się od jej „regularnych oddziałów”.

Zgodnie z zebranymi dowodami i relacjami świadków w rzeczywistości oddziałem kierowali emir i shura. Emir nadzorował wszelkie kwestie wojskowe i cywilne, w tym reprezentował oddział w stosunkach zewnętrznych, np. z dowództwem Armii BiH. Przez większą część okresu istnienia El Mudžahid przedmiotowe stanowisko zajmował Algierczyk Abu Maali. Dowódca wojskowy oddziału, który przewodził radzie militarnej, był podporządkowany emirowi i odpowiadał za planowanie oraz przeprowadzanie operacji bojowych.

Najwyższym organem decyzyjnym El Mudžahid była shura - rada religijna składająca się z około 20 członków, głównie pochodzenia arabskiego, posiadająca ostateczny głos w istotnych sprawach oddziału. Shura wybierała emira, który był przed nią odpowiedzialny, a jego decyzje mogły być przez radę zmienione bądź całkowicie odrzucone.

Jak donosili przesłuchiwani przez MTK świadkowie, pod koniec 1994 roku faktycznym dowódcą oddziału, wprawdzie niezajmującym oficjalnie tego stanowiska, został przybyły do Bośni szejk Anwar Shaban, założyciel Islamskiego Ośrodka Kultury w Mediolanie, mający szereg powiązań z siatką islamskich organizacji terrorystycznych na świecie. Był on odpowiedzialny za rekrutację ochotników do walk w Bośni w krajach arabskich oraz przerzut mudżahedinów i broni na teren walk. Shaban miał uprawnienie do wydawania wiążących rozkazów dla oddziału, a jego autorytet i decyzje nigdy nie były kwestionowane przez shurę. Szejk zginął w 1995 roku na chorwackim punkcie kontrolnym w Bośni wraz z trzema wysokimi rangą dowódcami oddziału mudżahedinów.

W odróżnieniu od regularnych oddziałów Armii BiH członkowie El Mudžahid nie posiadali stopni wojskowych. Wojownicy podzieleni byli na mniejsze jednostki bojowe, nie nosili mundurów, insygniów czy wojskowych dokumentów identyfikacyjnych. Posiadali za to własny sztandar (flagę) z białym napisem w języku arabskim na czarnym tle.

Istotną cechą charakterystyczną oddziału była waga, jaką przykładano do postępowania zgodnie z instrukcjami i nakazami islamu. Naruszenie zasad religijnych mogło skutkować usunięciem z szeregów. Przykładowo zagraniczny mudżahedin nie mógł poślubić lokalnej kobiety przed upływem sześciu miesięcy od swego przybycia do Bośni, a zgodę na ślub musieli wyrazić inni członkowie oddziału.

Większość walczących pod sztandarem El Mudžahid rekrutowała się z krajów arabskich, w szczególności z Algierii, Egiptu bądź z Arabii Saudyjskiej. Byli to mężczyźni, którzy całe swoje życie poświęcili walce w imię islamu i krzewieniu ideałów salafizmu bądź wahabizmu. Niemniej jednak częściowo jednostkę zasilali też rekruci z innych krajów, w tym konwertyci z USA czy Europy Zachodniej.

18 J.R. Schindler, Unholy Terror..., s. 167. 


\section{INNE JEDNOSTKI WOJSKOWE ODWOŁUJĄCE SIĘ DO IDEI DŻIHADU}

Oprócz przedstawionego powyżej oddziału El Mudžahid po stronie bośniackich muzułmanów w trakcie wojny z lat 1992-1995 walczyły także inne jednostki odwołujące się do idei dżihadu. Najbardziej znaną z nich była 7 Muzułmańska Brygada Armii $\mathrm{BiH}$ sformowana w listopadzie 1992 roku. Składała się ona z najbardziej radykalnych w poglądach bośniackich rekrutów, którzy walczyli przede wszystkim w imię Allaha, a w drugiej dopiero kolejności w obronie bośniackiego państwa. W zamyśle prezydenta Izetbegovicia 7 Brygada miała być wzorem jednostki wojskowej przyszłej armii muzułmańskiej Bośni. Jej istnienie, podobnie jak oddziału El Mudžahid, miało raczej charakter polityczny niż militarny. Brygada, tak jak wspomniany oddział mudżahedinów, słynęła przede wszystkim ze swojej ideologicznej zawziętości i okrutnego działania w stosunku do wrogów, za których uważano wszystkich przedstawicieli innych niż islam religii, a nawet mniej ortodoksyjnych wyznawców Allaha.

W Armii BiH powołano do życia także dwie inne jednostki bośniackich ochotników odwołujące się do ideałów dżihadu - 4 Muzułmańską Lekką Brygadę oraz 9 Muzułmańską Brygadę Wyzwoleńczą. Jednak wszystkie wymienione jednostki, chociaż miały do odegrania rolę wojskową, nie wywarły istotnego wpływu na przebieg walk.

Dowódcy Armii BiH [...] uważali ich wktad w dziatania wojenne za minimalny, zauważajac równocześnie, że ich chęć do atakowania wroga wynikata raczej zniepohamowanego pędu do walki, która miata uczynić z nich męczenników, niż z faktycznego pragnienia wygrania kolejnych bitew ${ }^{19}$. Wielu zastanawiało się również, dlaczego El Mudžahid oraz 7 Muzułmańska Brygada spędziły wojnę w centralnej Bośni, gdzie muzułmanie byli stosunkowo najbezpieczniejsi, a nie zostały nigdy przerzucone w rejon Sarajewa czy doliny Driny, gdzie muzułmanie byli otoczeni przez siły nieprzyjaciela i istniała faktyczna potrzeba prowadzenia walk (np. celem ochrony ludności cywilnej) ${ }^{20}$. Jakie jest wytłumaczenie tych okoliczności? Dla części komentatorów jest ono oczywiste - obecność mudżahedinów w Bośni byta potrzebna kierownictwu SDA z powodów czysto ideologicznych, a nie militarnych. [...] Bojownicy grali role ideologicznej awangardy reżimu, a także istotnego symbolu międzynarodowego poparcia dla sprawy ${ }^{21}$.

\section{MUDŻAHEDINI A POROZUMIENIE Z DAYTON}

Zgodnie z Porozumieniem z Dayton zawartym w grudniu 1995 roku, kończącym formalnie wojnę w Bośni: Wszystkie jednostki i oddziaty wojskowe w Bośni i Hercegowinie, które $w$ dniu wejścia w życie niniejszego Aneksu nie sa jednostkami miejscowego

19 Tamże, s. 170.

20 Tamże.

21 Tamże. 
pochodzenia bądź które nie sa prawnie lub militarnie podporządkowane wtadzom Bośni i Hercegowiny, Federacji Bośni i Hercegowiny badź Republice Serbskiej w Bośni, maja zostać wycofane z terytorium Bośni i Hercegowiny wraz ze swoim wyposażeniem w ciagu $30 \mathrm{dni} i^{22}$.

Mimo żądań zgłaszanych przez przedstawicieli społeczności międzynarodowej dotyczących egzekucji powyższych zapisów mających doprowadzić do wydalenia mudżahedinów z terenów świeżo zakończonego konfliktu, władze w Sarajewie z dość ograniczonym zaangażowaniem podjęły działania w celu ich realizacji. SDA pod przywództwem Izetbegovicia, mimo oficjalnych deklaracji, nie kwapiły się do wydalenia z kraju obcych wojowników. Wręcz przeciwnie, bośniacki wywiad starał się ukryć przed społecznością międzynarodową, w tym siłami IFOR/SFOR, dalszą obecność mudżahedinów na terytorium Bośni i Hercegowiny.

Rząd w Sarajewie postanowił umożliwić bojownikom osadnictwo w centralnej Bośni, licząc, że umknie to uwadze zarówno większości społeczeństwa, jak i przede wszystkim międzynarodowych sił stabilizacyjnych. W konsekwencji duża liczba islamskich wojowników pozostała na terytorium kraju, uzyskując poprzez zawarte z lokalnymi kobietami małżeństwa status rezydentów. W wielu przypadkach pojawienie się weteranów z jednostki El Mudžahid budziło opór miejscowej ludności, nieakceptującej niezwykle konserwatywnych poglądów zagranicznych bojowników. Co więcej, ci „nowi obywatele", często w brutalny sposób, starali się narzucić wahabickie ideały sąsiadom, nierzadko w stosunku do opornych na ich światopogląd posuwając się do zastraszeń, pobić, a niekiedy także zabójstw. Mimo sprzeciwu bośniackiej ludności władze w Sarajewie roztaczały nad mudżahedinami parasol ochronny, zamiatając pod dywan wszelkie ich występki i zbrodnie. Co więcej, działalność bojowników nie była także przedmiotem nadmiernego zainteresowania sił SFOR, które zdawały się ignorować wszelkie doniesienia o działalności byłych mudżahedinów na terytorium Bośni.

Szacunkowe dane wskazują, że w czasie wojny zaginęło blisko 12 tys. bośniackich paszportów ${ }^{23}$, z których większość mogła trafić w ręce członków organizacji terrorystycznych ${ }^{24}$. Co więcej, pod koniec wojny kierownictwo SDA zdecydowało się na wprowadzenie niezwykle łatwej ścieżki otrzymania bośniackiego obywatelstwa dla zagranicznych wojowników biorących udział w świętej wojnie. Zasady naturalizacji pozwalały bowiem uzyskać obywatelstwo niemalże każdemu islamskiemu bojownikowi bądź pracownikowi organizacji humanitarnej. Jako obywatele Bośni i Hercegowiny osoby te nie były zobowiązane do opuszczania kraju, co przewidywało w stosunku do obcych jednostek wojskowych Porozumienie z Dayton. Zebrane przez lata materiały wskazują, że na przełomie 1995 i 1996 roku 741 mudżahedinów walczących w Bośni otrzymało bośniackie obywatelstwo. Naturalizowano także setki innych, którzy ni-

22 The General Framework Agreement for Peace in Bosnia and Herzegovina with Annexes, Annex 1A: Agreement on the Military Aspects of the Peace Settlement, artykuł 3, 14 XII 1995.

23 Tamże, s. 239.

24 Liczne doniesienia wskazują, że także Osama bin Laden posiadał bośniacki paszport, który został mu najprawdopodobniej wydany w 1993 roku w Ambasadzie Bośni i Hercegowiny w Wiedniu. 
gdy nie walczyli i nie mieszkali w Bośni. Tym samym na Bałkanach osiedliło się wielu obcokrajowców, dla których prowadzona przez nich wojna nigdy ostatecznie się nie zakończyła ${ }^{25}$.

Zintegrowali się oni z lokalną społecznością, posiadają bośniackie obywatelstwo, a wielu z nich przyjęło nawet miejscowe nazwiska. W konsekwencji istniała i nadal istnieje trudność w ustaleniu ich faktycznego pochodzenia, co umożliwia wielu z nim prowadzenie działalności, w tym także tej o charakterze terrorystycznym.

\section{POWOJENNA RZECZYWISTOŚĆ}

Pierwsze lata po zakończeniu wojny były bardzo trudne dla nowo powstałej republiki Bośni i Hercegowiny. Problemy społeczne, wysoka przestępczość, słaba gospodarka, tworzące się w bólach struktury administracji państwowej, policji czy wojska - wszystko to decydowało o polityczno-organizacyjnym chaosie, który w dalszym ciągu pozwalał licznym organizacjom o charakterze terrorystycznym rozwijać swoje wpływy na Bałkanach. Organizacje te, wspierane zwłaszcza przez bogate kraje Zatoki Perskiej, prowadziły intensywną działalność, choć musiały robić to mniej jawnie niż w czasach konfliktu, co wynikało z obecności sił IFOR.

Sytuacja wewnętrzna kraju pozwalała na rozwój szeregu kolejnych pozarządowych organizacji, które propagowały wśród mieszkańców ideę powrotu do korzeni islamu i dążyły do przekształcenia Bośni w kraj islamski. Najbardziej znaną organizacją, która pojawiła się po wojnie na politycznej scenie, była Active Islamic Youth (Aktivna Islamska Omladina - AIO), powołana do życia w 1995 roku w Zenicy. Jej celem było dążenie do utworzenia w Bośni państwa islamskiego i promocja konserwatywnego islamu odwołującego się do źródeł tej religii. Założyli ją członkowie rozwiązanego oddziału El Mudžahid, którzy werbowali do organizacji przede wszystkim młodych weteranów, sieroty wojenne i tradycyjnie konserwatywną ludność z prowincjii ${ }^{26}$. W ciągu pierwszych lat istnienia organizacja rozrosła się do kilku tysięcy członków i otworzyła swoje przedstawicielstwa na terenie całej Federacji Bośni i Hercegowiny. Propagując ideały wahabitów, członkowie AIO występowali nie tylko przeciw wyznawcom innych religii, ale także przeciw muzułmanom odrzucającym głoszoną przez nich wersję islamu ${ }^{27}$.

Działalność AIO uzależniona była przede wszystkim od finansowania z Arabii Saudyjskiej, nieszczędzącej grosza na propagowanie idei wahabizmu na europejskiej ziemi. Transfery pieniężne opiewały na setki tysięcy dolarów. Dodatkowo Rijad zaangażował się w akcję odnawiania oraz budowy nowych meczetów. Najbardziej okazałym budynkiem wzniesionym w ramach tych działań był meczet króla Fahda na przedmieściach

25 Kwestię naturalizacji podejmuje także m.in. A.C. Lugert, Preventing and Combating Terrorism in Bosnia and Herzegovina, Vienna 2002, s. 56-59.

26 Tamże, s. 70.

27 S. Oluic, Radical Islam on Europe's Frontier - Bosnia \& Herzegovina, „National Security and the Future" 2008, Vol. 1-2, nr 9, s. 43. 
Sarajewa, będący centrum wahabistycznej propagand $y^{28}$. Ciągle prężnie działające islamskie organizacje pozostawały pod wpływem Al-Ka’idy. Osama bin Laden wspierał finansowo walki w imię islamu poprzez dwa działające w Bośni banki: Vakufska Banka i Depozitna Banka, które rozdzielały fundusze na rzecz innych islamskich organizacji.

Sytuacja wewnętrzna powojennej Bośni i Hercegowiny była tak zagmatwana, że działania odwetowe mudżahedinów na niewierzących często nie trafiały do publicznej wiadomości. W pierwszym pięcioleciu po zakończeniu wojny na terenie Bośni popełniono wielu czynów o charakterze kryminalnym bądź terrorystycznym, często przypisywanych islamskim bojownikom, którzy najczęściej unikali grożących im kar, salwując się ucieczką poza granice kraju. Wśród najbardziej medialnych działań podejmowanych po wojnie były zamordowanie ministra spraw wewnętrznych Bośni i Hercegowiny (Chorwata) Jozo Leutara w 1999 roku czy też próba dokonania zamachu na papieża Jana Pawła II podczas jego pielgrzymki do Bośni w $1997 \mathrm{roku}^{29}$.

Działalność świętych wojowników nie ograniczała się jedynie do terenów Bośni i Hercegowiny. Wielu z nich, korzystając z posiadanych bośniackich paszportów, podróżowało po świecie celem organizowania kolejnych ataków. W 1999 roku na lotnisku w Stambule turecka policja zatrzymała jednego z wysoko postawionych członków Al-Ka'idy Mehreza Amdouniego. Ten naturalizowany Bośniak, urodzony w Tunezji, był członkiem oddziału El Mudžahid, a po zakończeniu wojny przeniósł się do Włoch, gdzie kontynuował swoją działalność, biorąc udział w przygotowywaniu kolejnych ataków terrorystycznych. Był poszukiwany między innymi przez władze włoskie pod zarzutem organizowania zamachu na ministrów włoskiego rządu.

W tym samym czasie w Kanadzie udaremniono inny zamach terrorystyczny, za organizacją którego stali weterani bośniackiego konfliktu. Ahmed Ressam, Fateh Kamel i Karim Said Atmani, działając w okolicach Montrealu, planowali przeprowadzić zamach terrorystyczny na lotnisko w Los Angeles pod koniec 1999 roku. Wszyscy trzej mieli w swoim życiorysie epizod bośniacki, a Kamel i Atmani walczyli razem w oddziale El Mudžahid. Podczas pobytu na Bałkanach posiedli wiedzę o konstruowaniu bomb czy prowadzeniu „podwójnego życia” pozwalającego na przygotowanie ataków terrorystycznych. Dochodzenie władz kanadyjskich wykazało, że atak planowano ściśle według wskazówek kierownictwa Al-Ka’idy. Tylko na skutek błędów najmniej doświadczonego z całej trójki Ressama udało się udaremnić planowaną akcję.

Powyższe działania stanowią tylko część przykładów aktywności weteranów bośniackiej świętej wojny po zakończeniu konfliktu na Bałkanach. Pomimo ich wykrycia oraz wykazania związków terrorystów z Bośnią władze w Sarajewie w dalszym ciągu zdawały się ignorować całą sytuację, zaprzeczając jakimkolwiek powiązaniom Bośni $\mathrm{z}$ międzynarodowym terroryzmem.

28 Szerzej zob. V. Attanassoff, Islamic Revival..., s. 33.

29 Więcej na temat zamachów terrorystycznych w Bośni zob. I. Lučić, Bosnia and Herzegovina..., s. 129-135. Warto także zaznaczyć, że wielu mudżahedinów, po odbyciu szkolenia w warunkach wojennych, wyjechało walczyć w imię Allaha do innych krajów, przede wszystkim do Czeczenii, celem wsparcia lokalnej ludności w starciach z rosyjskimi wojskami, ale także do Kosowa - wspierać Armię Wyzwolenia Kosowa (alb. Ushtria Çlirimtare e Kosovës - UKC). 
Nastawienie bośniackich władz zaczęło się zmieniać dopiero na skutek zamachu na World Trade Center przeprowadzonego 11 września 2001 roku w Nowym Jorku. Sarajewo, pod wpływem USA, zmuszone zostało do opowiedzenia się wreszcie po którejś ze stron $\mathrm{w}$ wojnie z terroryzmem. 11 września byt punktem zwrotnym, który doprowadzit do zblizenia bośniackiego rzadu oraz USA w kwestii zwalczania terroryzmu. Co więcej, identyfikacja co najmniej dwóch z porywaczy ${ }^{30}$ [samolotu z 9 września - przyp. M.F.] jako wojowników walczacych po stronie bośniackich muzutmanów w czasie wojny domowej pociagnęta za soba zwiększenie czujności i doktadności dziatań Bośni. Izetbegović zostat ofiara tej zmiany, będąc zmuszonym do rezygnacji ze stanowiska przywódcy [...] SDA miesiac po atakach $w$ Nowym Jorku ${ }^{31}$.

Początkowo zmiany w nastawieniu Sarajewa do kwestii związków Bośni z terroryzmem były umiarkowane (i budziły niezadowolenie części najbardziej konserwatywnych środowisk), niemniej z czasem proces zmian stał się bardziej widoczny, co można przypisywać coraz większym naciskom ze strony Waszyngtonu, który postrzegał Batkany jako region potencjalnie narażony na dziatania terrorystów ze względu na znaczna populacje muzutmanów, stabą kontrole granicznq i mato skuteczne sity bezpieczeństwa ${ }^{32}$.

Działania te przybrały realne kształty w postaci podejmowanych przez Sarajewo inicjatyw legislacyjnych. Przy pomocy amerykańskich ekspertów powołano do życia Państwową Agencję Śledczą i Ochrony, której zadaniem była między innymi walka $\mathrm{z}$ terroryzmem. Utworzono także Komisję ds. Weryfikacji Obywatelstwa, powierzając jej zadanie wyjaśnienia nieprawidłowości związanych z przyznawaniem bośniackiego obywatelstwa w czasie wojny i krótko po jej zakończeniu. Jej prace potwierdziły podejrzenia, że proces naturalizacji pełen był nieprawidłowości, a szereg osób, w tym także obcokrajowców, otrzymało w tym czasie bośniackie obywatelstwo nielegalnie ${ }^{33}$.

\section{ZAKOŃCZENIE}

Nie budzi wątpliwości, że konflikt z początku lat 90. XX wieku oraz pierwsze lata istnienia nowego tworu państwowego stworzonego mocą Porozumienia z Dayton, jakim jest Bośnia i Hercegowina, w tym zwłaszcza sprawowanie rządów przez SDA pod przywództwem Aliji Izetbegovicia, umożliwiły licznym organizacjom terrorystycznym, w tym Al-Ka’idzie, uzyskanie „przyczółku” operacyjnego w Europie. Wojna w Bośni stanowiła doskonały poligon wojskowy dla mudżahedinów, którzy mogli szlifować swoje umiejętności bojowe na prawdziwym polu walki. Równocześnie pojawienie się na Bałkanach wojowników Allaha głoszących idee islamu wahabickiego pozwoliło na rekrutację kolejnych, tym razem europejskich, ochotników do walki z niewiernymi.

30 Chodzi o Khalida al-Mihdhara i Nawafa al-Hazmiego, którzy pomogli w porwaniu samolotu American Airlines lot numer 77, który uderzył w budynek Pentagonu.

31 S. Oluic, Radical Islam..., s. 40.

32 National Commission on Terrorist Attacks upon the United States, The 9/11 Commission Report, 2004, s. 366-367, [online] http://www.9-11 commission.gov/report, 26 V 2014.

33 S. Oluic, Radical Islam..., s. 46. 
Należy zgodzić się z twierdzeniem, że idee radykalnego islamu spotkały się z ograniczoną popularnością wśród mieszkańców Bośni i Hercegowiny, niemniej jednak zostały „zasiane” na obrzeżach Unii Europejskiej ${ }^{34}$ i do dzisiaj dają o sobie znać. Świadczyć może o tym chociażby istnienie wahabickich społeczności, takich jak Gornja Maoča, z którą związany był Mevlid Jašarević -zamachowiec z Sarajewa. Ta górska enklawa zamieszkiwana jest przez 30 rodzin mudżahedinów, w większości bośniackiego pochodzenia, żyjących według nakazów wahabizmu, kwestionujących zwierzchnictwo władz i służb państwowych Sarajewa. Społeczność została założona w 2002 roku na wzór zlikwidowanej przez bośniackie władze wspólnoty w wiosce Donja Bočinja. Społeczność Gornja Maoča żyje według prawa szariatu, dzieci uczęszczają do szkół zorganizowanych na wzór jordański, gdzie językiem wykładowym jest arabski. Tablice w wiosce również są w języku arabskim. Miejscowy meczet został wzniesiony dzięki dotacjom z Arabii Saudyjskiej i Jordanii, a mieszkańcy wioski pozostają poza kontrolą bośniackiej wspólnoty muzułmańskiej.

Wioska przez lata była pod obserwacją wywiadowczą zarówno wywiadów zagranicznych, jak i bośniackiego, mimo to, ze względu na fakt pozostawania w kompletnej izolacji, trudno było ustalić faktyczną sytuację, jaka panowała w tej zamkniętej społeczności. Próby przeprowadzenia jakichkolwiek działań w wiosce kończyły się niepowodzeniem, w tym także atakami na interweniujących oficerów policji. W związku z doniesieniami o posiadaniu przez część mieszkańców kontaktów z organizacjami terrorystycznymi władze w Sarajewie zdecydowały się w lutym 2010 roku na przeprowadzenie w wiosce zakrojonej na szeroką skalę operacji z udziałem 650 policjantów, wspieranych przez członków służby granicznej, agencji wywiadu i bezpieczeństwa wewnętrznego oraz ciężki sprzęt. W trakcie działań operacyjnych zatrzymano siedmiu mieszkańców wioski, w tym przywódcę wahabickiej społeczności Nusreta Imamovicia, oraz skonfiskowano znaczny arsenał broni, amunicji, materiałów wybuchowych i gotówki nieznanego pochodzenia ${ }^{35}$. Oficjalnie działania przeprowadzono pod zarzutem, że istnienie społeczności Gornja Maoča stanowi zagrożenie dla integralności terytorialnej kraju, umożliwia szerzenie nienawiści etnicznej i działanie nielegalnego systemu szkolnictwa. Mimo przeprowadzonej operacji i dokonanych zatrzymań nie doszło jednak do całkowitej likwidacji wioski.

Istnienie społeczności takich jak Gornja Maoča niepokoi i świadczy o tym, że blisko 20 lat po zakończeniu Porozumieniem z Dayton bośniackiego konfliktu Bośnia i Hercegowina w dalszym ciągu boryka się z problemem obecności mudżahedinów na swoim terytorium, co stanowi zagrożenie nie tylko dla tej bałkańskiej republiki, ale także dla bezpieczeństwa regionalnego. Przypominają o tym takie wydarzenia, jak choćby zamach na amerykańską ambasadę w Sarajewie. W corocznym raporcie o zagrożeniach terrorystycznych na świecie amerykański Departament Stanu podkreśla, że w dalszym ciągu potencjalne zagrożenie w Bośni i Hercegowinie stanowią wpływy radykalnych nurtów islamskiego ekstremizmu, niemniej jednak kraj podejmuje systematyczne działania mające na

34 Tamże, s. 48.

35 A. Alic, Bosnian Forces Conduct Massive Wahabi Raid, International Relations and Security Network, Swiss Federal Institute of Technology Zurich, [online] http://www.isn.ethz.ch/layout/set/print/content/view/full/24620?lng=en\&id=112328, 26 V 2014. 
celu ograniczenie tego problemu. W raporcie podkreśla się w szczególności współpracę głównych społeczności religijnych na rzecz promocji tolerancji i przeciwdziałania religijnemu ekstremizmowi oraz potępienie przez część muzułmańskich duchownych udziału bośniackich muzułmanów w zagranicznych konfliktach, np. w Syriii ${ }^{36}$. Takie zmiany dają nadzieję, że utrzymanie obranego przez Sarajewo kursu w kwestii walki z terroryzmem pozwoli na uporanie się ze skutkami obecności mudżahedinów na Bałkanach.

\section{BIBLIOGRAFIA}

Alic A., Bosnian Forces Conduct Massive Wababi Raid, International Relations and Security Network, Swiss Federal Institute of Technology Zurich, [online] http://www.isn.ethz.ch/ layout/set/print/content/view/full/24620?lng=en\&id=112328.

Attanassoff V., Islamic Revival in the Balkans, Monterey, Calif. 2006.

Bell M., In Harm's Way. Bosnia. A War Reporter's Story, London 2012.

Bosnia US Embassy Gunman Mevlid Jasarevic Jailed for 18 Years, BBC News, [online] http:// www.bbc.co.uk/news/world-europe-20629893.

Ceresnjes A., Green R., Ruch globalnego dżihadu w Bośni - bomba zegarowa w sercu Europy, przeł. M. Koraszewska, The MEMRI, VI 2012.

The General Framework Agreement for Peace in Bosnia and Herzegovina with Annexes, Annex

1A: Agreement on the Military Aspects of the Peace Settlement, artykuł 3, 14 XII 1995.

Glenny M., The Fall Yugoslavia. The Third Balkan War, London-New York 1996.

House Republican Policy Committee, Policy Perspective. The Clinton Administration's „Wink and Nod" to Allow Iran into Bosnia. Iran-Bosnia Credibility Gap, 26 IV 1996.

Lučić I., Bosnia and Herzegovina and Terrorism, „National Security and the Future” 2001, Vol. 3-4, nr 2.

Lugert A.C., Preventing and Combating Terrorism in Bosnia and Herzegovina, Vienna 2002.

National Commission on Terrorist Attacks upon the United States, The 9/11 Commission Report, 2004, s. 366-367, [online] http://www.9-11 commission.gov/report.

Oluic S., Radical Islam on Europe's Frontier - Bosnia \& Herzegovina, „National Security and the Future" 2008, Vol. 1-2, nr 9.

Schindler J.R., Unholy Terror. Bosnia, Al-Qaida and the Rise of Global Jihad, St. Paul 2007.

U.S. Department of State, Country Reports on Terrorism 2013, [online] http://www.state.gov/j/ $\mathrm{ct} / \mathrm{rls} / \mathrm{crt} / 2013 / 224822 . \mathrm{htm}$.

36 U.S. Department of State, Country Reports on Terrorism 2013, [online] http://www.state.gov/j/ct/rls/ crt/2013/224822.htm, 28 V 2014.

Mgr Mateusz FISZER - student studiów doktoranckich w Instytucie Nauk Politycznych i Stosunków Międzynarodowych UJ; jego zainteresowania naukowe koncentrują się wokół szeroko rozumianej problematyki integracji europejskiej, w tym przede wszystkim Wspólnej Polityki Zagranicznej i Bezpieczeństwa UE oraz zagadnień związanych z regionem Bałkanów Zachodnich. 